\title{
Geological setting and petrochemistry of early Middle Devonian volcanic and gabbroic rocks in the Guysborough area, Nova Scotia
}

\author{
C.F.M. Cormier ${ }^{1}$, S.M. Barr ${ }^{1}$, and G.R. Dunning ${ }^{2}$ \\ 'Department of Geology, Acadia University, Wolfville, Nova Scotia BOP IXO, Canada \\ 2Department of Earth Sciences, Memorial University of Newfoundland, \\ St. John's, Newfoundland AIB 3X5, Canada
}

Date Received June 5, 1995

Date Accepted December 12, 1995

\begin{abstract}
Mapping, petrological studies, and U-Pb dating of volcanic and plutonic units have provided a new understanding of the stratigraphy and paleotectonic setting of rocks in the Guysborough area. From base to top, the stratigraphic sequence is interpreted to consist of: (1) volcanic flows and pyroclastic rocks, with minor interlayered sedimentary rocks (Sunnyville Formation), (2) varied conglomerate (Glenkeen Formation), (3) quartz wacke with minor interlayered quartz arenite and conglomerate, and (4) massive to shaly or laminated siltstone. These volcanic and sedimentary units are intruded by small gabbroic plutons, sills, and dykes. All the units are early Middle Devonian, based on a U-Pb (zircon) age of $389 \pm 2 \mathrm{Ma}$ for rhyolitic tuff from the Sunnyville Formation, and a preliminary U-Pb (baddeleyite) age of ca. $385 \mathrm{Ma}$ for one of the gabbroic plutons in the siltstone unit.

Based on whole-rock chemistry, the mafic volcanic and gabbroic rocks are similar, and formed in a continental within-plate setting. However, the rocks in the eastern part of the map area are more alkalic than those in the west, which are dominantly tholeiitic. The mafic magmas are interpreted to have formed by partial melting of the subcontinental upper mantle and to have evolved by crystal fractionation processes; the more alkalic magmas in the east may represent lesser amounts of partial melting in that area. This interpretation is consistent with the presence of felsic volcanic rocks only in the western part of the area. They may represent crustal melts formed as a result of mafic magma underplating of the crust.

The regional tectonic significance of these igneous rocks is not yet resolved, but they are clearly older than Late Devonian to Carboniferous igneous units elsewhere in northern mainland Nova Scotia and in Cape Breton Island with which they were previously assumed to be correlative.
\end{abstract}

Des travaux de cartographie, des études pétrologiques et la datation au U-Pb d'unités volcaniques et plutoniques ont permis une meilleure compréhension de la stratigraphie et du cadre paléotectonique des roches du secteur de Guysborough. On interprète la composition de la séquence stratigraphique comme suit, de sa base à son sommet : 1) des écoulements volcaniques et des roches pyroclastiques, avec une proportion mineure de roches sédimentaires intercalées (Formation Sunnyville); 2) un conglomérat diversifié (Formation Glenkeen); 3) de la wacke qurtzeuse avec une présence mineure de conglomérat et de quartzite sédimentaire interstratifiés; et 4) des siltstones massifs à schisteux ou feuilletés. Ces unités volcaniques et sédimentaires sont pénétrées par de petits dykes, filonscouches et plutons gabbroiques. Toutes les unités remontent au début du Dévonien moyen d'après une datation au $\mathrm{U}-\mathrm{Pb}$ (zircon) situant à $389+2 \mathrm{Ma}$ le tuf rhyolitique de la Formation Sunnyville ainsi qu'une datation au U-Pb (baddeleyite) situant provisoirement l'un des plutons gabbroïques de l'unité de siltstones à environ $385 \mathrm{Ma}$.

D'après la chimie des roches, les roches volcanomafiques et gabbroïques sont semblabes et elles se sont formées dans un cadre intra-plaque continental. Les roches de la partie orientale du secteur cartographique sont cependant plus alcalines que celles de l'ouest, en prédominance tholéiitiques. Selon l'interprétation avancée, les magmas mafiques se seraient formés par suite d'une fonte partielle du manteau sous-continental supérieur et ils auraient évolué au moyen de processus de différenciation magmatique; les magmas plus alcalins de l'est pourraient représenter une fonte partielle moins importante dans ce secteur. Cette interprétation est compatible avec la présence de roches volcano-felsiques limitée à la partie ouest du secteur. Elles pourraient représenter des éléments crustaux fondus formés par suite d'une remontée de magma mafique sous les plaques de la croute.

On n'a pas encore déterminé l'importance tectonique régionale de ces roches ignées, mais elles sont clairement plus anciennes que les unités ignées du Dévonien supérieur au Carbonifère des autres régions de l'intérieur de la Nouvelle-Écosse et de l'île du Cap-Breton avec lesquelles on les supposait auparavant corrélatives.

[Traduit par la rédaction]

\section{INTRODUCTION}

Although the presence of volcanic and plutonic rocks in the Guysborough area (Fig. 1) was previously known from regional mapping (Schiller, 1961, 1963), their distribution, stratigraphic relations, petrochemistry, and age were poorly constrained prior to the present study. The mafic volcanic rocks were considered to be of Devonian to Carboniferous 


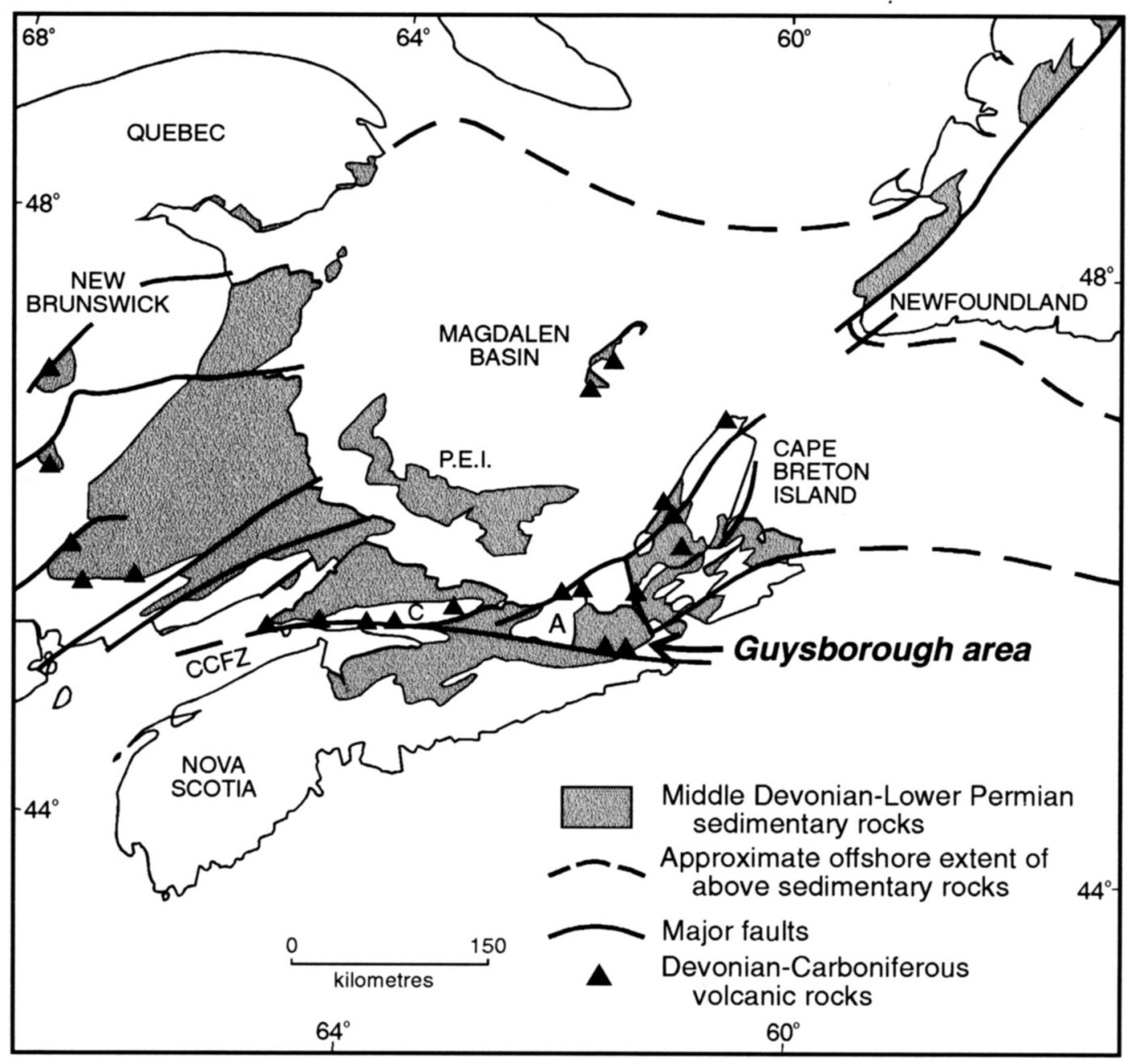

Fig. 1. Map of Nova Scotia, New Brunswick, and adjacent areas showing the distribution of Devonian and Carboniferous volcanic rocks. The arrow indicates the location of the Guysborough map area in northern mainland Nova Scotia. C = Cobequid Highlands; A $=$ Antigonish Highlands; $\mathrm{CCFZ}=$ Cobequid-Chedabucto Fault Zone (Minas Fault Zone).

age (Schiller, 1961, 1963; Mooney, 1990), whereas associated mafic plutonic rocks were interpreted to be late Palaeozoic (Schiller, 1963; Durocher, 1974) or Mesozoic (Donohoe and Grantham, 1989). Felsic volcanic rocks in the area were inaccurately described as "granite" and interpreted to be Mesozoic (Schiller, 1963) or Devonian - Carboniferous (Keppie, 1979; Donohoe and Grantham, 1989). Limited chemical data from mafic volcanic rocks near the town of Guysborough had been interpreted to indicate alkalic affinity (Mooney, 1990). The relationship of these rocks to the widespread mid-Paleozoic magmatism elsewhere in the region (Fig. 1), however, had not been assessed.

During 1992 and 1993, geological mapping at a scale of 1:25,000 was conducted in the Guysborough area (Fig. 2 ), to better determine the distribution, field relations, and characteristics of igneous rocks in the area. Petrographic and chemical analyses were done to provide a data base for the interpretation of chemical affinity, petrogenesis, and tectonic setting, and a rhyolite unit was dated using the U-Pb (zircon) method. The purpose of this paper is to present the results of this work, which formed the basis of a M.Sc. thesis by the senior author (Cormier, 1994).

\section{Geology of the Guysborough area}

\section{Introduction}

The present study and previous mapping (Schiller, 1961, 1963; Smith, 1980, 1981; Hill, 1987, 1991; Mooney, 1990) show that the stratigraphic succession in the Guysborough area consists of four units (from bottom to top): (1) volcanic flows and pyroclastic rocks, with minor interlayered sedimentary rocks, (2) varied conglomeratic rocks, (3) quartz wacke with minor interlayered quartz arenite and conglomerate, and (4) massive to shaly laminated siltstone (Fig. 2). Gabbroic plutons, sills, and dykes have intruded all of these units, but no definitely extrusive rocks were found in the sedimentary units.

The terminology for stratigraphic units in the Guysborough area has not been well established. Schiller (1963) used the name Black Settlement formation for the volcanic rocks; the more appropriate term Sunnyville Formation was introduced by Mooney (1990) for the volcanic rocks in the eastern part of the area around the community of Sunnyville (formerly Black Settlement) west of Guysborough. We sug- 


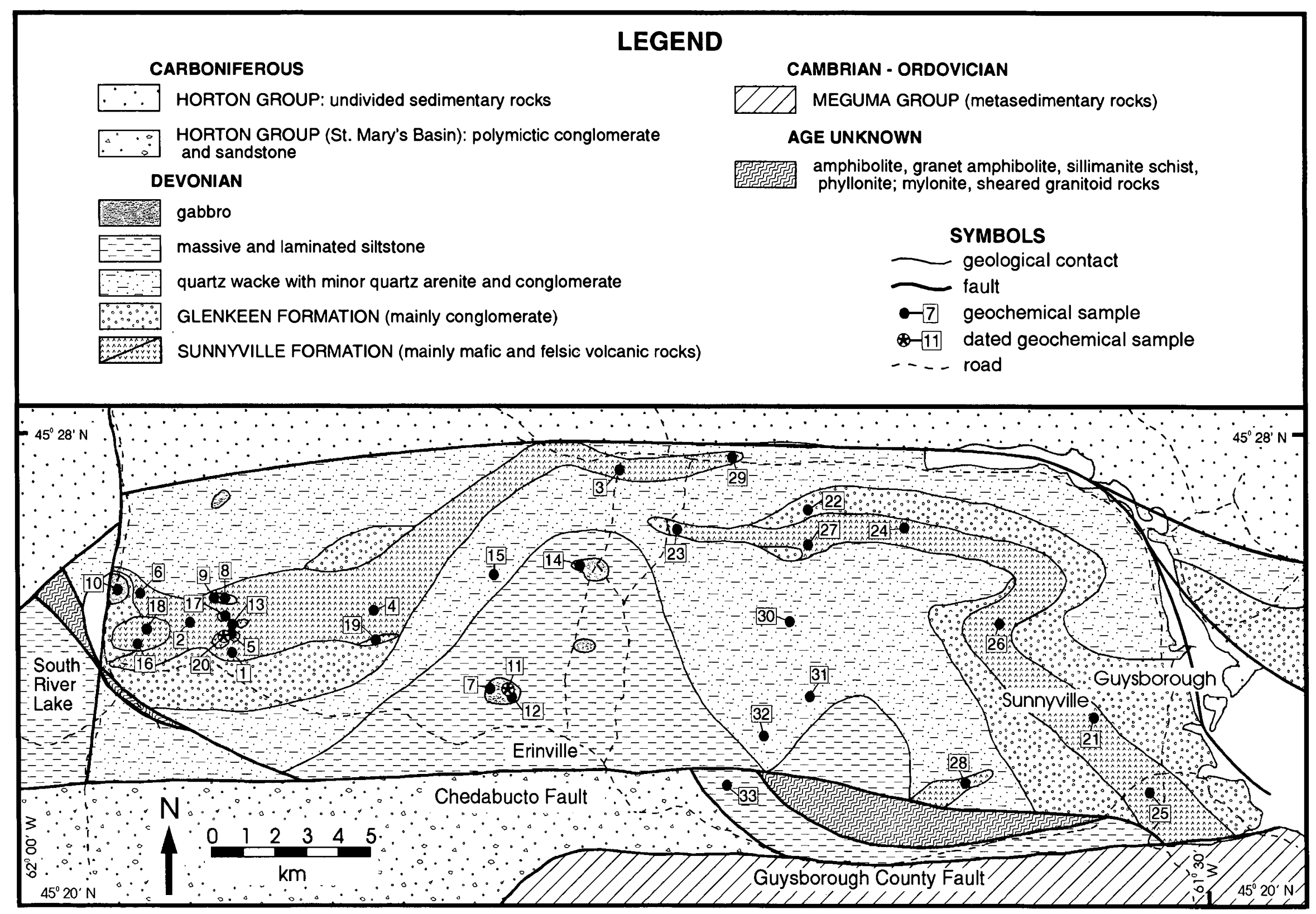

Fig. 2. Simplified geological map of the Guysborough area, modified from Cormier (1994) and Barr and White (1995). 
gest that Sunnyville Formation be accepted as the formal name for the mainly volcanic unit which occurs throughout the present map area (Fig. 2), with characteristics as described below.

The Glenkeen Formation was previously established (Smith, 1980,1981 , and in Williams et al., 1985) as the formal name for the mainly conglomeratic unit overlying the volcanic rocks of the Guysborough area, with the type section in the area east of the present study area. Hence that name is retained here, although a detailed report on the area has not been published, and Mooney (1990) used the term Tower formation for the same unit. The Glenkeen Formation was considered to be part of the Horton Group by Smith in Williams et al. (1985); however, the geochronological data presented here show that the conglomeratic rocks, as well as the overlying quartz wacke and siltstone units, are of early Middle Devonian age, and hence not part of the Horton Group.

Cormier (1994) interpreted the overlying quartz wacke and siltstone units to be members within the Carboniferous Clam Harbour River Formation of Smith $(1980,1981$, and in Williams et al., 1985). However, more recent mapping to the north of the present map area has shown that these units are unlikely to be part of the Clam Harbour River Formation (Barr and White, 1995), and hence they are here left unnamed, pending more detailed work in the area.

The four stratigraphic units in the study area are in faulted contact with Carboniferous sedimentary rocks of the Horton Group on the north and west (Fig. 2). On the south, they are complexly terminated by the Chedabucto, Guysborough County, and subsidiary faults, which separate the units from faulted slivers of varied metamorphic rocks of uncertain age, metasedimentary rocks of the Meguma terrane (Hill, 1987, 1991), and Carboniferous sedimentary rocks of the Horton Group in the St. Mary's basin (e.g., Murphy et al., 1993).

Structural data indicate that the Sunnyville and Glenkeen formations, as well as the overlying quartz wacke and siltstone units, were folded about an east-northeast fold axis, and refolded subsequently about a north-northeast fold axis in the southeastern part of the map area (Cormier, 1994).

\section{Sunnyville Formation}

The Sunnyville Formation consists of subaerial mafic and felsic flows and pyroclastic rocks, with minor intercalated sedimentary rocks. The mafic volcanic rocks form a discontinuous belt across the map area from west to east, whereas the felsic volcanic rocks occur only in the west in small isolated areas within the mafic flows and tuffs (Fig. 2). Intercalated sedimentary rocks were found only in the eastern part of the area, and include red siltstone and polymictic conglomerate. The stratotype for the formation is suggested to be the section exposed on the road between Nickerson Lake and Rocky Lake, $3 \mathrm{~km}$ northwest of Sunnyville, as described by Mooney (1990). In the western part of the area, a representative section is exposed along the Hoppenderry Road, $1 \mathrm{~km}$ northwest of Giant Lake (Cormier, 1994). The base of the formation is not exposed; Mooney (1990) estimated a minimum thickness of $1400 \mathrm{~m}$ in the Sunnyville area.
Mafic volcanic rocks in the western part of the map area are fine grained, dark green, and massive to amygdaloidal, whereas those in the eastern part of the map area tend to be more medium grained, variable in colour from dark green to maroon, and locally feldspar porphyritic as well as amygdaloidal. Basalts in the eastern part of the area locally display peperitic structures, indicating interaction with water-rich sediments. The major minerals in the basalts from both the east and west are plagioclase and augite in approximately equal proportions, with up to $10 \%$ opaque phases (magnetite and hematite). Texture varies from subophitic to intersertal or felty. Plagioclase is partially altered to sericite and saussurite, and clinopyroxene to chlorite and epidote. Other secondary minerals include titanite and opaques. Amygdules are filled with chlorite, carbonate, chalcedony, and/or zeolite minerals.

Subordinate mafic pyroclastic rocks are intercalated with the basaltic flows, forming a larger component in the eastern part of the area than in the west. They are mainly basaltic lapilli tuffs, composed of $>90 \%$ massive and vesiculated mafic lithic fragments in a matrix of chlorite, epidote and devitrified material. Up to $5 \%$ plagioclase crystal fragments and more abundant opaque (hematitic) material are present in the tuffs in the eastern part of the area.

The felsic rocks include both flows and welded tuffs. Flows are buff to purple, locally banded (due to flow), and quartz-feldspar phyric. In thin section, they display spherulitic, eutaxitic, and (locally) granophyric textures, and typically consist of a cryptocrystalline matrix, with $<2 \%$ subhedral, embayed quartz grains and $<2 \%$ anorthoclase crystals. Pyroclastic rocks include rhyolitic lithic crystal and lithic crystal vitric tuffs. The lithic crystal tuffs range from dark grey to buff to purple, and display well developed layering and flowbanding. An altered glassy to cryptocrystalline matrix, in places spherulitic, contains 2 to $4 \%$ angular to subangular, embayed quartz and 5\% subangular anorthoclase crystals, the latter displaying sericitic alteration and rare twinning, and $<1 \%$ subangular exotic lapilli of quartz arenite and siltstone. The vitric tuffs are massive, pale green, and consist of a glassy matrix of $>50 \%$ shards, with $<2 \%$ subhedral, embayed quartz grains and $<1 \%$ subhedral anorthoclase grains. Secondary minerals in the felsic samples include epidote, chlorite, sericite, carbonate, and iron oxides.

\section{Glenkeen Formation}

The Glenkeen Formation in the map area mainly flanks the Sunnyville Formation (Fig. 2), and consists of narrow, elongate lenses of grey-green to maroon, polymictic conglomerate with minor intercalated quartz wacke beds. The polymictic conglomerates are well indurated, poorly sorted, and immature. They contain angular to subrounded clasts up to $15 \mathrm{~cm}$ in diameter, including, in order of decreasing abundance, quartz wacke, siltstone, basalt, lithic crystal tuff, rhyolite and quartz, in a silty matrix of clay minerals, Fecarbonate, Fe-oxides, chlorite, epidote, and sericite.

Contacts between the Glenkeen Formation and underlying Sunnyville Formation are not exposed. Volcanic clasts of Sunnyville Formation lithologies in the Glenkeen For- 
mation, bedding orientations, and rare indications of younging direction based on cross- and graded bedding, however, indicate that the Glenkeen Formation concordantly and possibly conformably overlies the Sunnyville Formation. Smith in Williams et al. (1985) reported the presence of an inferred angular unconformity between the two formations, but that was not observed during the present study.

\section{Quartz wacke unit}

The quartz wacke unit occurs both north and south of the Sunnyville and Glenkeen formations. It consists mainly of dark grey-blue to grey, massive to faintly bedded quartz wacke with minor quartz arenite and oligomictic conglomerate. The quartz wacke is moderately well sorted, composed of 35 to $60 \%$ quartz grains cemented by carbonate material, with accessory zircon, pyrite and tourmaline.

\section{Siltstone unit}

The siltstone unit occurs west of the South River Lake fault, in a large area south of the quartz wacke member in the central part of the map area, and in a large fault-bounded belt in the southeastern part of the map area. It consists of dark grey, massive to shaly siltstone and lighter grey or locally grey-green, laminated siltstone, with minor interbedded quart $z$ wacke (beds $<5 \mathrm{~cm}$ thick) and pyrite nodules $(<4 \mathrm{~cm}$ long).

\section{Gabbroic rocks}

Small, gabbroic plutons are exposed at scattered locations in the western and central parts of the map area (Fig. 2). The gabbroic rocks range from dark green to black, and from fine- to coarse-grained. They display intergranular to subophitic textures, consisting of plagioclase and clinopyroxene of augitic composition, with accessory opaque phases, apatite, and titanite. The gabbro east of South River Lake also contains up to $30 \%$ forsteritic olivine. The gabbro northwest of Erinville (herein termed the Erinville gabbro) contains abundant accessory phases, particularly apatite (3\%), compared to the other plutons. Drillcore from the Erinville gabbro indicates that it becomes increasingly anorthositic with depth (Cormier, 1994; Dickie, 1989). The large gabbro body north of the Erinville gabbro contains fine grained gabbroic xenoliths of similar composition to the coarser grained host.

In addition to the plutons, gabbroic sills and dykes were found in the Sunnyville and Glenkeen formations, and in the overlying quartz wacke and siltstone units, mainly in the southeastern part of the map area, although these intrusions are too small to show at the scale of Figure 2. Intrusive contacts between mafic sills and dykes and the quartz wacke were observed. The gabbroic sills and dykes are dark green to black, fine- to medium-grained, equigranular to inequigranular with intersertal, intergranular or subophitic texture dominated by plagioclase and clinopyroxene, with accessory apatite and opaque minerals. The plagioclase is partially altered to sericite, saussurite and epidote, and clinopyroxene is strongly altered to chlorite and epidote.

\section{Metamorphic rocks}

Metamorphic rocks are exposed in a narrow belt, about $11 \mathrm{~km}$ in length and $1.5 \mathrm{~km}$ wide, north of the Guysborough County Fault in the eastern part of the map area, and in faulted blocks and slivers in the South River Lake area in the western part of the map area. Contacts between these rocks and adjacent units are not exposed, and it is assumed that they have been faulted into their present positions. The eastern belt is mainly composed of strongly laminated and foliated phyllonite, with one area of garnet sillimanite schist. In thin section, micas in the phyllonite show extreme parallelism, and pressure shadows occur around quartz grains. The garnet sillimanite schist contains fine grained quartz, red-brown biotite, sillimanite, and garnet, with bands and lenses of disaggregated white quartz parallel to the foliation. The western fault-bounded areas consist of amphibolite and sheared granitoid rocks. The amphibolite is mylonitic.

The age and origin of these metamorphic rocks is uncertain. Similar rocks are exposed elsewhere along the Minas Fault System at Clarke Head in the Bay of Fundy (Gibbons and Murphy, 1993), in the Melrose area (Edmonds, 1990), and on Isle Madame (Barr et al., 1992; Barr and White, 1995).

\section{U-Pb DaTing}

In order to better constrain the age of the volcanic rocks, a sample of rhyolite in which accessory zircon was observed in thin section was selected for $\mathrm{U}-\mathrm{Pb}$ dating. The dated sample is a welded tuff, containing broken crystals of plagioclase, anorthoclase, and embayed quartz in a cryptocrystalline to glassy (welded) groundmass. Rare, rhyolitic lithic clasts are also present.

Zircon was obtained from the bulk crushed rock sample using a Wilfley table and further concentrated using a combination of heavy liquids and magnetic separation. Mineral separates were hand-picked under a microscope to obtain high quality, morphologically similar grains. Zircon fractions were abraded using the technique of Krogh (1982). Analytical methods were as described by Dunning et al. (1990). Uncertainties on the ages are reported at the $95 \%$ confidence level.

Four fractions of abraded zircon grains were analyzed (Table 1). Two fractions $(\mathrm{Z2}, \mathrm{Z3})$ contain trace amounts of inheritance and hence are slightly discordant; the third fraction is concordant at $389 \mathrm{Ma}$ (Fig. 3). All three fraction have ${ }^{206} \mathrm{~Pb} /{ }^{38} \mathrm{U}$ ages of 388 to $389 \mathrm{Ma}$, and the best estimate of the crystallization age, based on the ${ }^{206} \mathrm{~Pb} /{ }^{238} \mathrm{U}$ ages and the concordant fraction, is $389 \pm 2 \mathrm{Ma}$. This age is early Middle Devonian according to the time scale of Okulitch (1995), which places the Early - Middle Devonian boundary at 392 $\pm 2 \mathrm{Ma}$.

A sample from the Erinville gabbro (Fig. 2) was subsequently selected for $\mathrm{U}-\mathrm{Pb}$ dating. Preliminary concordant 


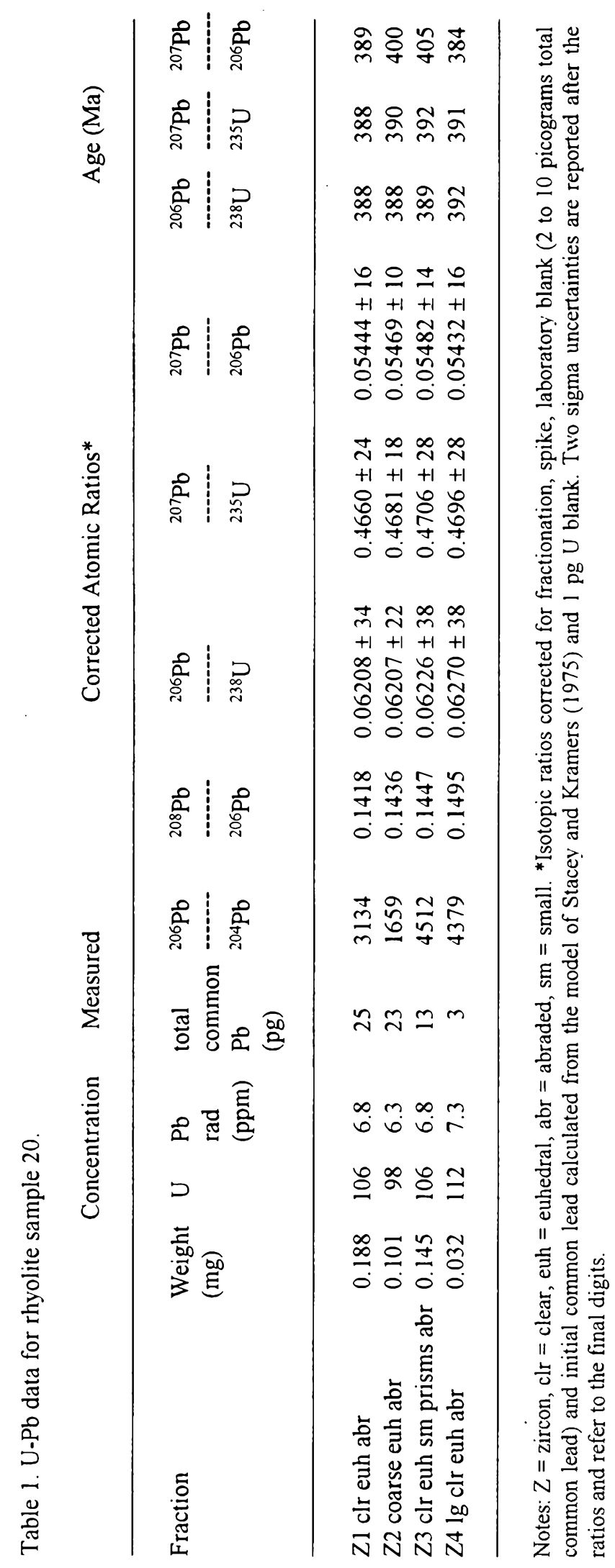

results from baddeleyite in this sample indicate an age of ca. $385 \mathrm{Ma}$ (G. Dunning, unpublished data), showing that the gabbroic and volcanic rocks have similar early Middle Devonian ages.

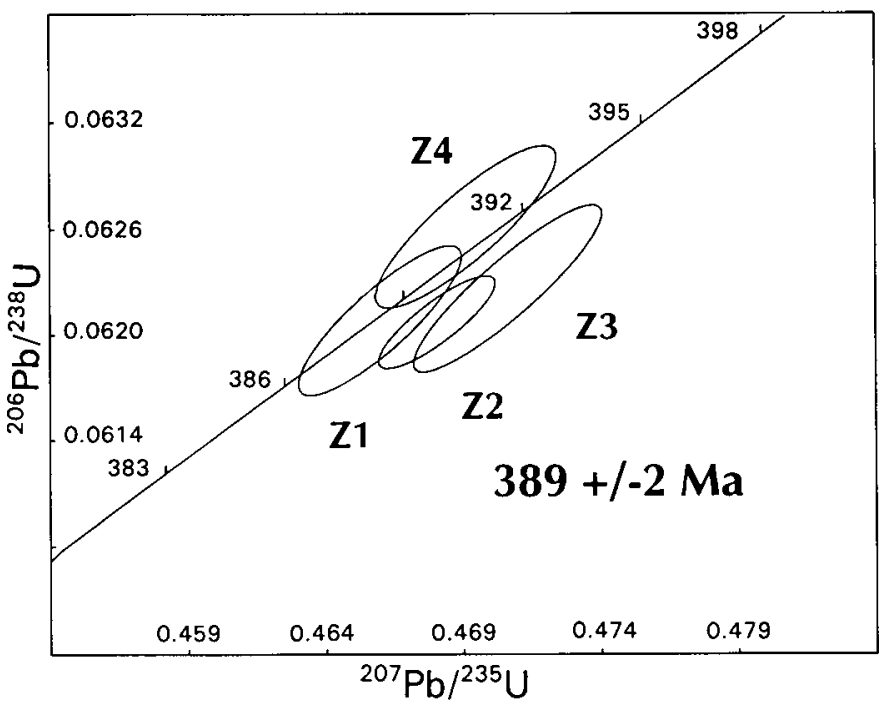

Fig. 3. Concordia diagram for rhyolite sample $\# 20$ (location shown in Fig. 2). Data in Table 1.

\section{GeOCheMistry \\ Introduction}

Thirty-three samples were selected for whole-rock chemical analysis from volcanic and gabbroic outcrops throughout the map area (Fig. 2; Table 2). Samples were crushed and the freshest pieces were handpicked to avoid weathered surfaces, amygdules, and phenocrysts, prior to pulverization in a tungstencarbide mill. Analyses were done by standard X-ray fluorescence techniques at the Nova Scotia Regional Geochemical Centre, Saint Mary's University, Halifax. Seven of the samples, including 3 basalts, 2 rhyolites and 2 gabbros, with low loss on ignition values $(<3 \%)$ were also analyzed for rare earth elements (Table 3) by ICP-MS at Memorial University of Newfoundland, St. John's.

For purposes of comparison, volcanic and gabbroic samples from the western and eastern parts of the map area are plotted with separate symbols in the diagrams presented as the basis for the following discussion. The data of Mooney (1990) from the eastern part of the map area are shown for comparison on some of the diagrams.

\section{Chemical characteristics}

The mafic samples have $\mathrm{SiO}_{2}$ contents mainly between 45 and $52 \%$ (after recalculation to total $100 \%$ volatile-free); only four samples have higher values (Fig. 4a). The felsic samples all have recalculated $\mathrm{SiO}_{2}$ values of 76 to $83 \%$. Losson-ignition values are varied, especially in the mafic rocks, where they range up to $7 \%$, and combined with the petrographic evidence of alteration observed in the samples, indicate that caution should be used in interpreting chemical data, particularly for the generally mobile elements, such as $\mathrm{Na}_{2} \mathrm{O}$ and $\mathrm{K}_{2} \mathrm{O}$, which show wide variation (Fig. 4b, c). The high field strength elements (i.e., $\mathrm{Zr}, \mathrm{Nb}, \mathrm{Y}$ and $\mathrm{Ti}$ ) are 
Table 2a. Major and trace element data (in \% and ppm, respectively) for samples from the western part of the map area

\begin{tabular}{|c|c|c|c|c|c|c|c|c|c|c|c|c|c|c|c|c|c|c|c|c|}
\hline Map No. & . 1 & 2 & 3 & 4 & 5 & 6 & 7 & 8 & 9 & 10 & 11 & 12 & 13 & 14 & 15 & 16 & 17 & 18 & 19 & 20 \\
\hline & 3-MF & $11-M F F$ & 23-MF & 103-MF & 107-MF & 35-MT & 31-MI & 47-MI & 53-MI & $80-\mathrm{MI}$ & 83A-MI & 83B-MI & 108-MI & $120-\mathrm{MI}$ & 219-MI & 19-FT & $52-\mathrm{FF}$ & 93-FT & 104-FF & $109-\mathrm{F}$ \\
\hline $\mathrm{SiO}_{2}$ & 45.64 & 45.39 & 47.98 & 45.50 & 46.03 & 46.85 & 46.34 & 47.77 & 46.40 & 46.20 & 45.61 & 45.95 & 46.04 & 45.84 & 50.15 & 75.96 & 74.21 & 81.00 & 75.59 & 75.86 \\
\hline $\mathrm{Al}_{2} \mathrm{O}_{3}$ & 15.46 & 16.47 & 15.27 & 15.50 & 15.84 & 16.36 & 15.65 & 14.01 & 14.02 & 15.37 & 12.89 & 14.37 & 15.58 & 14.80 & 14.55 & 11.87 & 12.65 & 8.45 & 11.41 & 11.48 \\
\hline $\mathrm{Fe}_{2} \mathrm{O}_{3}$ & 12.98 & 13.49 & 14.42 & 10.83 & 13.94 & 14.83 & 13.49 & 14.34 & 13.36 & 12.30 & 15.66 & 14.20 & 13.75 & 15.65 & 12.22 & 2.81 & 2.07 & 3.51 & 3.00 & 3.66 \\
\hline $\mathrm{MgO}$ & 7.49 & 6.99 & 8.03 & 10.66 & 7.72 & 3.66 & 4.19 & 4.94 & 7.87 & 13.35 & 4.04 & 3.91 & 5.90 & 6.25 & 5.71 & 0.13 & 0.04 & 0.44 & 0.18 & 0.20 \\
\hline $\mathrm{CaO}$ & 8.33 & 8.21 & 4.27 & 6.27 & 6.30 & 5.55 & 8.78 & 8.18 & 9.08 & 6.85 & 8.66 & 8.84 & 9.34 & 5.61 & 5.14 & 0.30 & 0.94 & 1.02 & 0.26 & 0.32 \\
\hline $\mathrm{Na}_{2} \mathrm{O}$ & 3.01 & 2.48 & 3.85 & 0.47 & 3.56 & 3.88 & 3.54 & 4.03 & 3.13 & 2.30 & 3.16 & 4.31 & 2.71 & 3.30 & 4.01 & 2.46 & 2.29 & 0.57 & 2.56 & 1.88 \\
\hline $\mathrm{K}_{2} \mathrm{O}$ & 0.27 & 1.04 & 0.56 & 4.36 & 0.14 & 0.20 & 0.94 & 0.08 & 0.14 & 0.30 & 1.44 & 0.83 & 0.72 & 0.50 & 0.03 & 4.48 & 5.48 & 1.50 & 4.29 & 4.53 \\
\hline $\mathrm{TiO}_{2}$ & 2.50 & 2.37 & 1.79 & 1.41 & 2.18 & 2.73 & 3.16 & 2.43 & 1.79 & 1.10 & 3.78 & 3.66 & 2.68 & 3.82 & 3.07 & 0.23 & 0.15 & 0.19 & 0.23 & 0.24 \\
\hline $\mathrm{MnO}$ & 0.31 & 0.35 & 0.28 & 0.34 & 0.23 & 0.17 & 0.23 & 0.30 & 0.38 & 0.15 & 0.22 & 0.24 & 0.30 & 0.27 & 0.18 & 0.04 & 0.03 & 0.04 & 0.07 & 0.04 \\
\hline $\mathrm{P}_{2} \mathrm{O}_{5}$ & 0.27 & 0.37 & 0.33 & 0.15 & 0.34 & 0.52 & 1.30 & 0.23 & 0.20 & 0.37 & 1.62 & 1.57 & 0.46 & 0.74 & 0.43 & 0.02 & 0.02 & 0.03 & 0.02 & 0.02 \\
\hline LOI & 3.10 & 2.50 & 3.60 & 4.30 & 3.60 & 6.90 & 2.10 & 4.10 & 3.60 & 0.90 & 3.70 & 2.20 & 2.20 & 2.90 & 4.30 & 0.40 & 0.60 & 2.60 & 0.90 & 0.90 \\
\hline Total & 99.36 & 99.65 & 100.39 & 99.80 & 99.90 & 101.65 & 99.73 & 100.41 & 99.98 & 99.19 & 100.78 & 100.08 & 99.68 & 99.69 & 99.79 & 98.70 & 98.48 & 99.35 & 98.51 & 99.14 \\
\hline $\mathrm{Ba}$ & 194 & 839 & 203 & 1256 & 73 & 15 & 383 & 16 & 53 & 339 & 732 & 406 & 380 & 113 & 29 & 127 & 90 & 49 & 34 & 65 \\
\hline $\mathrm{Rb}$ & 7 & 21 & 13 & 53 & $<5$ & 8 & 7 & $<5$ & $<5$ & $<5$ & 28 & $<10$ & 23 & 19 & $<5$ & 126 & 274 & 80 & 178 & 145 \\
\hline $\mathrm{Sr}$ & 364 & 318 & 207 & 269 & 196 & 48 & 545 & 283 & 195 & 1154 & 509 & 470 & 413 & 313 & 900 & 13 & 12 & $<5$ & 15 & 10 \\
\hline Y & 36 & 31 & 29 & 26 & 27 & 45 & 64 & 32 & 25 & 11 & 67 & 66 & 40 & 36 & 27 & 140 & 181 & 168 & 190 & 161 \\
\hline $\mathrm{Zr}$ & 155 & 188 & 136 & 108 & 165 & 215 & 453 & 155 & 118 & 91 & 508 & 504 & 216 & 232 & 249 & 1026 & 1237 & 1177 & 1353 & 1157 \\
\hline $\mathrm{Nb}$ & 10 & 18 & 15 & 7 & 15 & 19 & 52 & 9 & 7 & 7 & 64 & 61 & 17 & 22 & 31 & 98 & 145 & 121 & 114 & 104 \\
\hline Th & $<10$ & $<10$ & $<10$ & $<10$ & $<10$ & $<10$ & $<10$ & $<10$ & $<10$ & $<10$ & $<10$ & $<10$ & $<10$ & $<10$ & $<10$ & 26 & 43 & 31 & 32 & 28 \\
\hline $\mathrm{Pb}$ & $<10$ & $<10$ & $<10$ & $<10$ & $<10$ & $<10$ & $<10$ & $<10$ & $<10$ & $<10$ & $<10$ & 17 & $<10$ & $<10$ & $<10$ & $<10$ & $<10$ & $<10$ & 11 & $<10$ \\
\hline $\mathrm{Ga}$ & 21 & 22 & 19 & 13 & 20 & 22 & 25 & 21 & 19 & 18 & 21 & 20 & 23 & 23 & 20 & 33 & 39 & 30 & 37 & 35 \\
\hline $\mathrm{Zn}$ & 393 & 139 & 121 & 121 & 107 & 42 & 126 & 102 & 96 & 85 & 103 & 345 & 162 & 155 & 161 & 18 & 32 & 15 & 59 & 24 \\
\hline $\mathrm{Cu}$ & 167 & 6 & $<5$ & $<5$ & 9 & 7 & 23 & 109 & 33 & 23 & 13 & 23 & 69 & 12 & 33 & $<5$ & $<5$ & $<5$ & 6 & 16 \\
\hline $\mathrm{Ni}$ & 960 & 86 & 165 & 264 & 86 & 53 & 29 & 27 & 60 & 306 & 8 & 15 & 53 & 88 & 75 & $<5$ & $<5$ & $<5$ & $<5$ & $<5$ \\
\hline V & 313 & 279 & 236 & 257 & 269 & 391 & 188 & 372 & 315 & 96 & 177 & 185 & 270 & 367 & 240 & 6 & $<5$ & $<5$ & $<5$ & $<5$ \\
\hline $\mathrm{Cr}$ & 176 & 76 & 293 & 606 & 70 & 120 & 10 & 34 & 429 & 524 & 5 & 5 & 93 & 135 & 201 & $<5$ & $<5$ & $<5$ & $<5$ & $<5$ \\
\hline
\end{tabular}

Sample type: $\mathrm{MF}=$ mafic flow, $\mathrm{MT}=$ mafic tuff, $\mathrm{MI}=$ mafic intrusion, $\mathrm{FF}=$ felsic flow, $\mathrm{FT}=$ felsic tuff. $\mathrm{LOI}=$ loss on ignition $\left(\%\right.$ weight loss after heating for 1 hour at $\left.1000^{\circ} \mathrm{C}\right)$ 
Table $2 \mathrm{~b}$. Major and trace element data (in $\%$ and $\mathrm{ppm}$, respectively) for samples from the eastem part of the map area.

\begin{tabular}{|c|c|c|c|c|c|c|c|c|c|c|c|c|c|}
\hline Map No. & 21 & 22 & 23 & 24 & 25 & 26 & 27 & 28 & 29 & 30 & 31 & 32 & 33 \\
\hline & 54-MT & 58-MT & 67-MF & 69-MF & 79-MF & 81-MF & 118-MF & 199-MF & 289-MF & 114-MI & 213-MI & 215-MI & 290-MI \\
\hline
\end{tabular}

\begin{tabular}{|c|c|c|c|c|c|c|c|c|c|c|c|c|c|}
\hline $\mathrm{SiO}_{2}$ & 48.67 & 53.42 & 46.69 & 49.82 & 55.32 & 49.45 & 50.28 & 51.44 & 44.58 & 46.36 & 46.39 & 43.92 & 45.80 \\
\hline $\mathrm{Al}_{2} \mathrm{O}_{3}$ & 15.55 & 16.08 & 16.44 & 18.23 & 15.25 & 16.34 & 16.82 & 15.12 & 15.76 & 16.23 & 14.70 & 15.69 & 15.92 \\
\hline $\mathrm{Fe}_{2} \mathrm{O}_{3}$ & 13.18 & 13.15 & 11.80 & 13.29 & 11.61 & 13.01 & 13.76 & 11.13 & 13.91 & 14.57 & 13.82 & 16.36 & 17.54 \\
\hline $\mathrm{MgO}$ & 4.75 & 4.43 & 6.73 & 5.66 & 4.25 & 7.12 & 3.11 & 6.25 & 5.76 & 4.53 & 6.81 & 5.24 & 7.27 \\
\hline $\mathrm{CaO}$ & 3.95 & 1.75 & 4.60 & 1.17 & 1.27 & 1.88 & 4.12 & 1.90 & 5.58 & 6.39 & 6.31 & 5.91 & 2.98 \\
\hline $\mathrm{Na}_{2} \mathrm{O}$ & 5.34 & 4.81 & 4.61 & 6.23 & 3.33 & 4.91 & 3.97 & 5.16 & 6.25 & 4.12 & 3.20 & 3.19 & 2.52 \\
\hline $\mathrm{K}_{2} \mathrm{O}$ & 1.62 & 1.00 & 0.29 & 0.21 & 2.69 & 0.26 & 2.35 & 0.09 & 0.29 & 1.06 & 1.23 & 3.05 & 0.86 \\
\hline $\mathrm{TiO}_{2}$ & 2.64 & 1.90 & 3.14 & 1.66 & 2.24 & 2.20 & 2.50 & 3.15 & 2.09 & 3.60 & 2.56 & 3.09 & 1.01 \\
\hline $\mathrm{MnO}$ & 0.16 & 0.07 & 0.14 & 0.34 & 0.10 & 0.20 & 0.07 & 0.12 & 0.22 & 0.24 & 0.23 & 0.23 & 0.10 \\
\hline $\mathrm{P}_{2} \mathrm{O}_{5}$ & 1.42 & 0.83 & 1.32 & 0.22 & 0.80 & 0.95 & 1.31 & 1.30 & 0.66 & 0.71 & 0.33 & 0.50 & 0.19 \\
\hline LOI & 2.60 & 3.00 & 3.40 & 3.80 & 3.30 & 3.40 & 2.40 & 3.90 & 5.20 & 1.90 & 4.10 & 2.10 & 5.70 \\
\hline Total & 99.85 & 100.44 & 99.16 & 100.63 & 100.16 & 99.71 & 100.69 & 99.57 & 100.30 & 99.71 & 99.67 & 99.28 & 99.87 \\
\hline $\mathrm{Ba}$ & 1076 & 210 & 261 & 103 & 349 & 81 & 693 & 92 & 134 & 251 & 360 & 472 & 185 \\
\hline $\mathrm{Rb}$ & 19 & 30 & $<5$ & 5 & 72 & 6 & 70 & $<5$ & 11 & 36 & 42 & 141 & 36 \\
\hline Sr & 205 & 193 & 922 & 267 & 98 & 157 & 379 & 245 & 343 & 565 & 705 & 435 & 172 \\
\hline$Y$ & 33 & 24 & 32 & 21 & 31 & 40 & 42 & 50 & 24 & 34 & 22 & 27 & 95 \\
\hline $\mathrm{Zr}$ & 347 & 259 & 298 & 89 & 249 & 274 & 385 & 319 & 234 & 345 & 168 & 211 & 90 \\
\hline $\mathrm{Nb}$ & 40 & 31 & 28 & 6 & 27 & 29 & 54 & 33 & 29 & 30 & 22 & 21 & 7 \\
\hline Th & $<10$ & $<10$ & $<10$ & $<10$ & $<10$ & $<10$ & $<10$ & $<10$ & $<10$ & $<10$ & $<10$ & $<10$ & $<10$ \\
\hline $\mathrm{Pb}$ & $<10$ & $<10$ & 22 & $<10$ & 10 & $<10$ & $<10$ & $<10$ & 10 & $<10$ & $<10$ & $<10$ & $<10$ \\
\hline $\mathrm{Ga}$ & 19 & 22 & 23 & 20 & 22 & 22 & 22 & 18 & 20 & 26 & 21 & 23 & 24 \\
\hline $\mathrm{Zn}$ & 126 & 33 & 169 & 317 & 125 & 84 & 40 & 89 & 162 & 71 & 165 & 77 & 42 \\
\hline $\mathrm{Cu}$ & 7 & $<5$ & 5 & $<5$ & 7 & $<5$ & 7 & $<5$ & $<5$ & 28 & 26 & 10 & $<5$ \\
\hline $\mathrm{Ni}$ & 83 & 114 & 145 & 90 & 65 & 117 & 36 & 81 & 90 & 18 & 69 & 62 & 87 \\
\hline V & 190 & 191 & 264 & 312 & 168 & 215 & 219 & 262 & 178 & 199 & 294 & 259 & 183 \\
\hline $\mathrm{Cr}$ & 115 & 166 & 211 & 193 & 85 & 132 & 86 & 136 & 183 & $<5$ & 83 & 12 & 255 \\
\hline
\end{tabular}

Sample type: $\mathrm{MF}=$ mafic flow, $\mathrm{MT}=$ mafic tuff, $\mathrm{MI}=$ mafic intrusion. $\mathrm{LOI}=$ loss on ignition $\left(\%\right.$ weight loss after heating for 1 hour at $\left.1000^{\circ} \mathrm{C}\right)$

generally considered to be less mobile during alteration and metamorphism (Pearce, 1982; Floyd and Winchester, 1978) and, on diagrams involving these elements, the samples from the study area generally plot in a linear pattern (e.g., Fig. 4d). This suggests that these elements may have been relatively immobile, or at least moved coherently during alteration, and hence diagrams involving ratios of these elements may be reliable indicators of pre-alteration chemical character.

A plot of $\mathrm{Zr} / \mathrm{TiO}_{2}$ against $\mathrm{Nb} / \mathrm{Y}$ (Fig. 5) shows that mafic samples vary from subalkalic to alkalic, based on $\mathrm{Nb} / \mathrm{Y}$ ratio. Mafic volcanic samples from the western part of the study area plot mainly in the subalkalic field, whereas samples from the eastern part of the study area plot mainly in the alkalic field, although there is considerable scatter. The data of Mooney (1990), all from the eastern part of the map area, are shown for comparison on this Figure 5 and also plot mainly in the alkalic field.

Felsic samples plot in the comendite-pantellerite field on Figure 5, as a result of their high $\mathrm{Zr}$ (1026 to $1353 \mathrm{ppm}$ ) and low $\mathrm{TiO}_{2}(<0.24 \%)$ values. However, the samples all have molecular $\left(\mathrm{Na}_{2} \mathrm{O}+\mathrm{K}_{2} \mathrm{O}\right)$ values less than $\mathrm{Al}_{2} \mathrm{O}_{3}$, and hence do not fit the definition of peralkaline rocks (Shand, 1947).

In Figure 5, three of four gabbroic dyke samples from the eastern part of the area plot in the alkalic field (the fourth sample has an anomalously low $\mathrm{Nb} / \mathrm{Y}$ ratio), in the same area as the associated volcanic rocks, whereas gabbroic samples from the west span the subalkalic and alkalic fields.

Multi-element variation diagrams (Fig. 6a-d) are used to further illustrate the chemical character of the mafic samples, with data normalized to the average mid-ocean ridge basalt of Pearce (1982). The wide variation in mobile elements such as $\mathrm{Rb}, \mathrm{Ba}$ and $\mathrm{K}_{2} \mathrm{O}$ is apparent in all four sample groups, in contrast to a relative lack of variation in $\mathrm{Nb}, \mathrm{P}_{2} \mathrm{O}_{5}, \mathrm{Zr}$, $\mathrm{TiO}_{2}$ and $\mathrm{Y}$. $\mathrm{Cr}$ and $\mathrm{Ni}$ show more variation, especially in the gabbroic samples, and this is attributed to variable degrees of pyroxene and olivine fractionation in the evolution of the mafic magmas. Most volcanic samples from the western part of the area (Fig. 6a) show overall flatter patterns, similar to the average within-plate tholeiitic basalt of Pearce (1982). In contrast, the volcanic samples from the eastern part of the area mainly show steeper patterns, more similar to that of the average within-plate alkalic basalt of Pearce 
Table 3. Rare-earth element data in ppm.

\begin{tabular}{lrrrrrrr} 
Map No. & 3 & 21 & 27 & 7 & 10 & 18 & 20 \\
\hline & & & & & & & \\
& $23(\mathrm{MF})$ & $54(\mathrm{MT})$ & $118(\mathrm{MF})$ & $31(\mathrm{MI})$ & $80(\mathrm{MI})$ & $93(\mathrm{FT})$ & 109 (FT) \\
& & & & & & & \\
\hline & & & & & & & \\
$\mathrm{La}$ & 13.23 & 33.76 & 20.57 & 59.90 & 14.81 & 63.15 & 92.14 \\
$\mathrm{Ce}$ & 30.17 & 75.09 & 51.96 & 135.61 & 33.63 & 156.25 & 181.65 \\
$\mathrm{Pr}$ & 3.92 & 12.01 & 7.53 & 16.56 & 4.21 & 19.48 & 24.63 \\
$\mathrm{Nd}$ & 16.30 & 53.48 & 33.69 & 68.80 & 17.14 & 76.31 & 99.13 \\
Sm & 3.86 & 11.42 & 8.25 & 14.09 & 3.33 & 20.09 & 23.11 \\
Eu & 1.17 & 3.65 & 2.68 & 3.98 & 1.19 & 0.65 & 0.69 \\
Gd & 4.53 & 10.16 & 8.27 & 13.35 & 3.04 & 23.61 & 24.39 \\
Tb & 0.67 & 1.23 & 1.16 & 1.74 & 0.34 & 3.86 & 3.39 \\
Dy & 4.45 & 6.72 & 7.12 & 10.84 & 2.19 & 26.33 & 22.67 \\
Ho & 0.79 & 1.08 & 1.25 & 1.99 & 0.36 & 5.05 & 4.16 \\
Er & 2.32 & 2.53 & 3.55 & 5.19 & 0.97 & 14.45 & 11.94 \\
Tm & 0.33 & 0.34 & 0.47 & 0.74 & 0.13 & 2.09 & 1.69 \\
Yb & 2.08 & 2.22 & 3.15 & 4.65 & 0.67 & 14.39 & 10.82 \\
Lu & 0.34 & 0.28 & 0.44 & 0.66 & 0.11 & 2.01 & 1.66 \\
Total REE & 84.16 & 213.97 & 150.09 & 338.10 & 82.12 & 427.72 & 502.07 \\
& & & & & & &
\end{tabular}

Sample type: $\mathrm{MF}=$ mafic flow, $\mathrm{MT}=$ mafic tuff, $\mathrm{MI}=$ mafic intrusive, $\mathrm{FT}=$ felsic tuff.

(1982). Gabbroic samples from both the eastern and western parts of the area show similar ranges of values, but more variation, even in the less mobile elements, than the volcanic rocks (Fig. 6b, d).

On a $\mathrm{Zr}$-Ti-Y discrimination diagram for mafic volcanic rocks (Fig. 7a), the samples, including those of Mooney (1990), mainly plot in the within-plate field. The more alkalic within-plate character of samples from the eastern part of the area is evident on the $\mathrm{Zr}-\mathrm{Nb}-\mathrm{Y}$ diagram (Fig. 7b). On these diagrams, the gabbroic samples show more variation than the basaltic samples, but overall have similar chemical characteristics. None of the geochemical diagrams suggest significant differences between the gabbroic and basaltic samples.

The felsic rocks have petrochemical characteristics similar to those of many A-type granitoid rocks, such as high $\mathrm{Zr}$ and $\mathrm{Ga} / \mathrm{Al}$ ratio (Fig. 8a), and high $\mathrm{Y}+\mathrm{Nb}$ (Fig. 8b). These features are consistent with origin by crustal melting in a within-plate tectonic setting (e.g., Pearce et al., 1984).

\section{Rare earth element chemistry}

A chondrite-normalized rare earth element (REE) plot for mafic volcanic and gabbroic samples shows enrichment in light REE relative to heavy REE, and enrichment of REE overall, compared to chondritic values (Fig. 9a). None of the samples show Eu anomalies, suggesting that plagioclase fractionation did not play a significant role in their evolution. The two mafic samples from the east show more enrichment in light REE compared to the mafic volcanic sample from the west. The latter sample also shows a flatter heavy
REE pattern. These differences are consistent with more alkalic affinity of the eastern volcanic samples, compared to tholeiitic affinity for the western sample, as also suggested by other chemical parameters discussed above. Enhanced light REE enrichment in alkalic magmas is related to a lesser degree of partial melting of the source (Wilson, 1989; Cullers and Graf, 1984; Hanson, 1980). The REE patterns are consistent with derivation from a garnet lherzolite mantle source, melting of which produced magmas with light REE enrichment because of the higher affinity of garnet for heavy REE compared to light REE (Hanson, 1980; Cullers and Graf, 1984). The REE patterns are similar to transitional tholeiitic to alkalic basalts from the East Africa Rift (Fig. 9a).

The two gabbroic samples bracket the other samples. The high REE abundance in the Erinville gabbro sample is consistent with its abundance of accessory phases such as zircon and apatite, which typically contain a high concentration of REE (e.g., Hanson, 1980).

Compared to the mafic samples, the two rhyolite samples have higher total REE, especially heavy REE, and a marked negative Eu anomaly (Fig. 9b). The large Eu anomaly may result from feldspar fractionation or, perhaps more likely, the presence of residual feldspar in the source during melting. Rhyolites from the East African Rift show similar REE patterns (Fig. 9b).

\section{Discussion}

The petrochemical data suggest that the basaltic rocks from the study area are mainly tholeiitic in the west and alkalic in the east, whereas gabbroic rocks are tholeiitic through- 


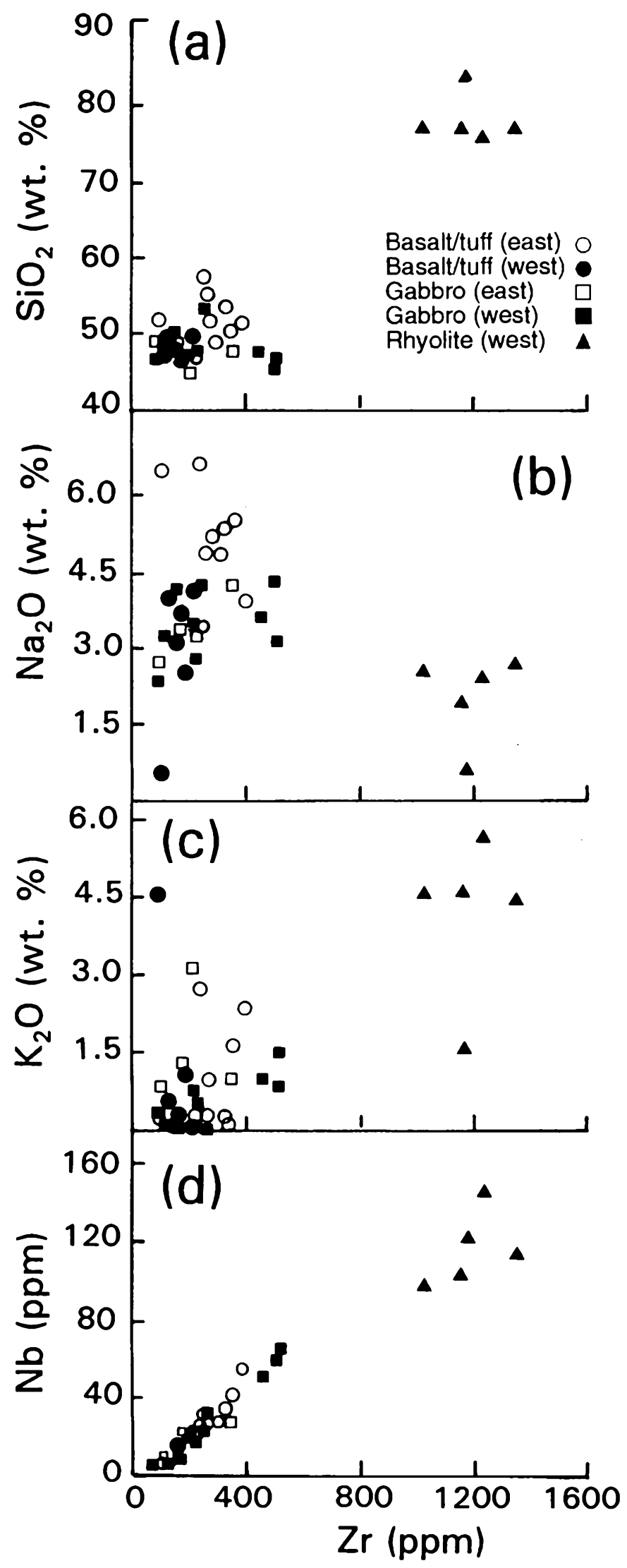

Fig. 4. Plots of $\mathrm{SiO}_{2}, \mathrm{Na}_{2} \mathrm{O}, \mathrm{K}_{2} \mathrm{O}$, and $\mathrm{Nb}$ against $\mathrm{Zr}$ for samples from the Guysborough area.

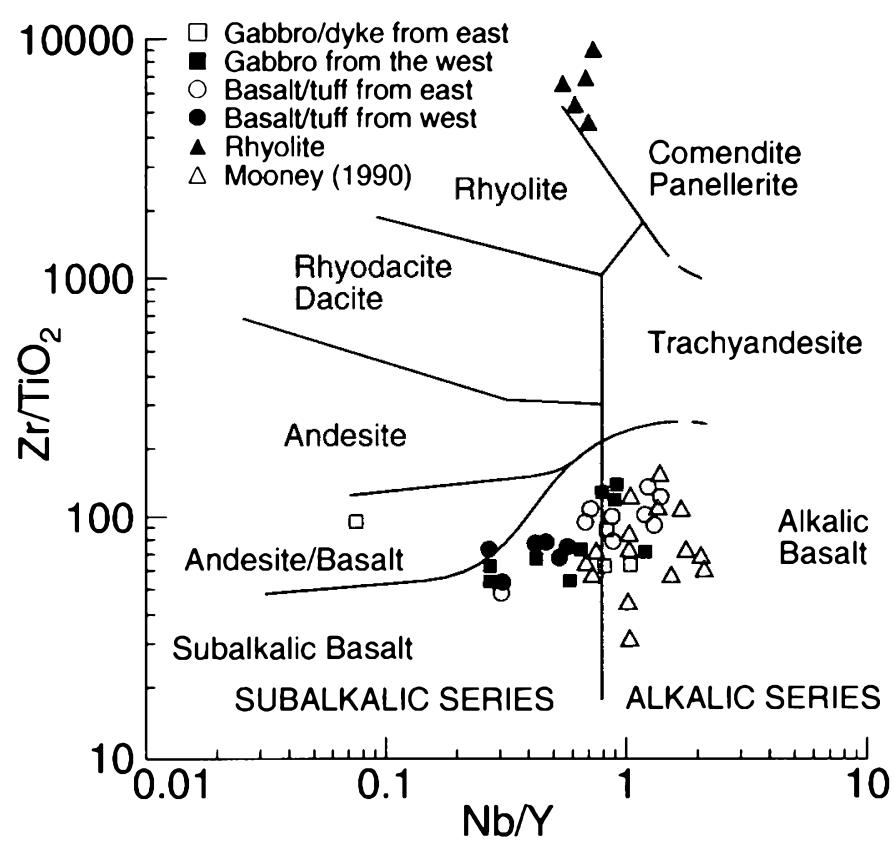

Fig. 5. Plot of $\mathrm{Nb} / \mathrm{Y}$ versus $\mathrm{Zr} / \mathrm{TiO}_{2}$ for samples from the Guysborough area. Mooney (1990) samples are basalts from the eastern part of the map area. Fields are from Winchester and Floyd (1977).

out the area. Both volcanic and gabbroic rocks formed in a continental within-plate setting, and most likely represent localized magmatism associated with rifting. Mafic volcanic rocks in the east have higher $\mathrm{SiO}_{2}$ content, are alkalic in character, and have a larger pyroclastic component than the dominantly tholeiitic volcanic rocks in the west. This suggests that rifting may have been more limited in the east, and consequently manifested by alkalic, more volatile-rich magmatism. Large degrees of partial melting of the source in the west could have produced magmas more tholeiitic in character. The magma was likely also to be more voluminous, and more likely to induce crustal melting, thus perhaps explaining the confinement of rhyolitic rocks to the western part of the area.

The volume of rhyolite relative to basalt in the study area is low enough to be explained by fractional crystallization processes. The marked $\mathrm{SiO}_{2}$ gap (55\%-73\%) and lack of chemical trends between mafic and felsic samples, however, suggests different sources for the mafic and felsic magmas. Hence crustal anatexis resulting from mafic magma underplating is a considered to be a likely origin for the felsic magmas. High contents of $\mathrm{Zr}, \mathrm{Y}, \mathrm{Nb}$ and $\mathrm{REE}$ suggest that zircon may have played a significant role in the petrogenesis of the felsic rocks. $\mathrm{Zr}$ contents of felsic rocks could be explained by zircon entrainment or melting of a $\mathrm{Zr}$-enriched source. Zircon is enriched in heavy REE, which can explain the flat chondrite-normalized pattern of the felsic samples, in contrast to the progressive depletion of heavy REE seen in the mafic rocks.

$\mathrm{Rb}-\mathrm{Sr}$ isotopic data for the volcanic and gabbroic rocks suggest an initial ${ }^{87} \mathrm{Sr} /{ }^{86} \mathrm{Sr}$ ratio of $0.7086 \pm 0.014$ ( $R$. Cormier, personal communication, 1994). This high ratio, compared 


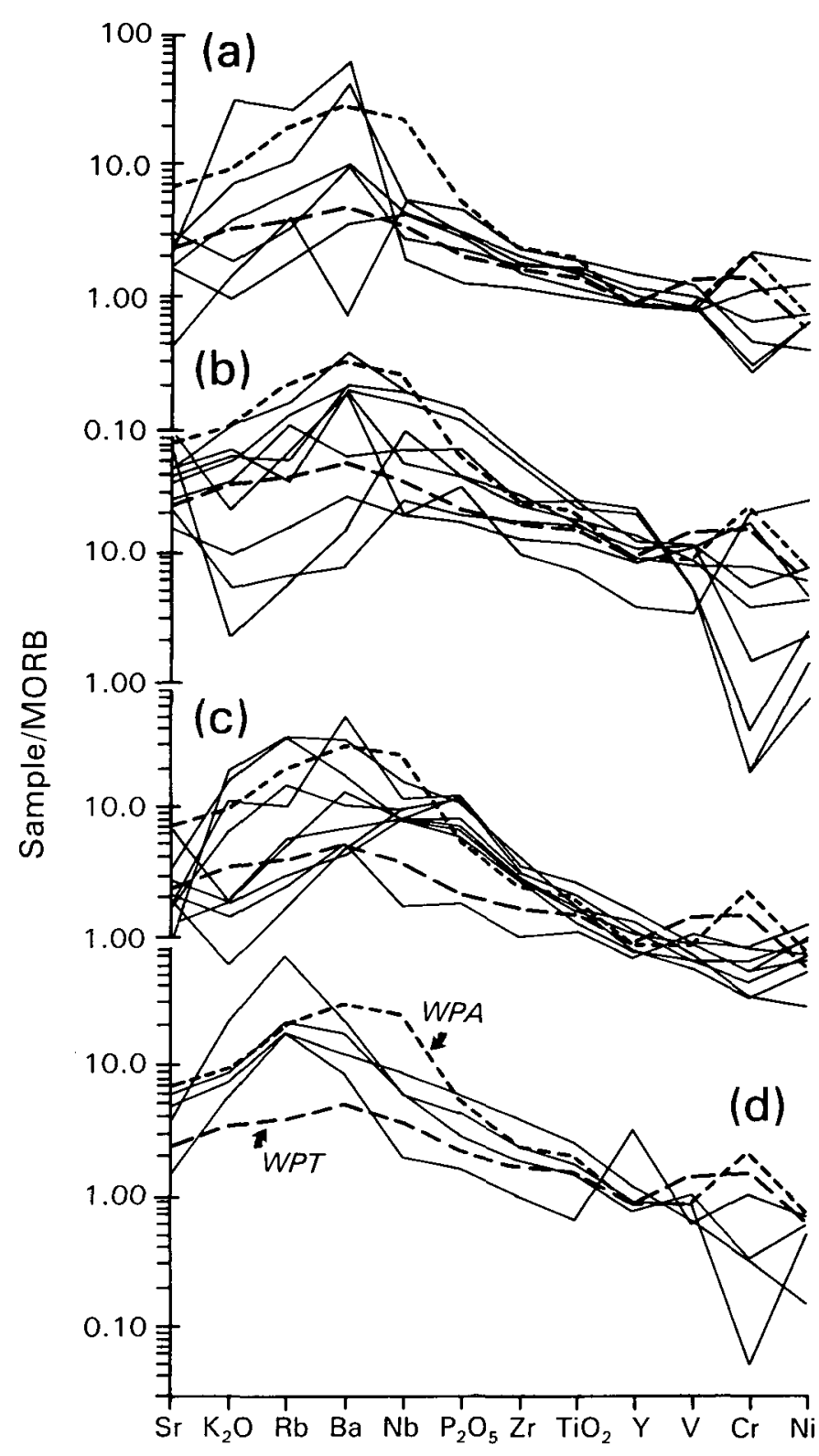

Fig. 6. Multi-element variation diagrams for (a) mafic volcanic samples from the western part of the Sunnyville Formation, (b) gabbroic samples from the western part of the map area, (c) mafic volcanic samples from the eastern part of the Sunnyville Formation, and (d) gabbroic samples from the eastern part of the map area. Data are normalized to average mid-ocean ridge basalt from Pearce (1982), except V value estimated from Shervais (1982). Dashed lines are average within-plate tholeiitic (WPT) and average within-plate alkalic (WPA) basalts from Pearce (1982).

to values of 0.702 to 0.704 that are typical of basalts derived from asthenospheric melts (Weaver and Tarney, 1981; Wilson, 1989), may be interpreted to indicate derivation from $\mathrm{Rb} / \mathrm{Sr}$ enriched or metasomatized mantle sources within the subcontinental lithosphere (Wilson, 1989).

\section{Discussion and conclusions}

Volcanic rocks in the Guysborough area have been previously assumed to be correlative with those of the Fisset

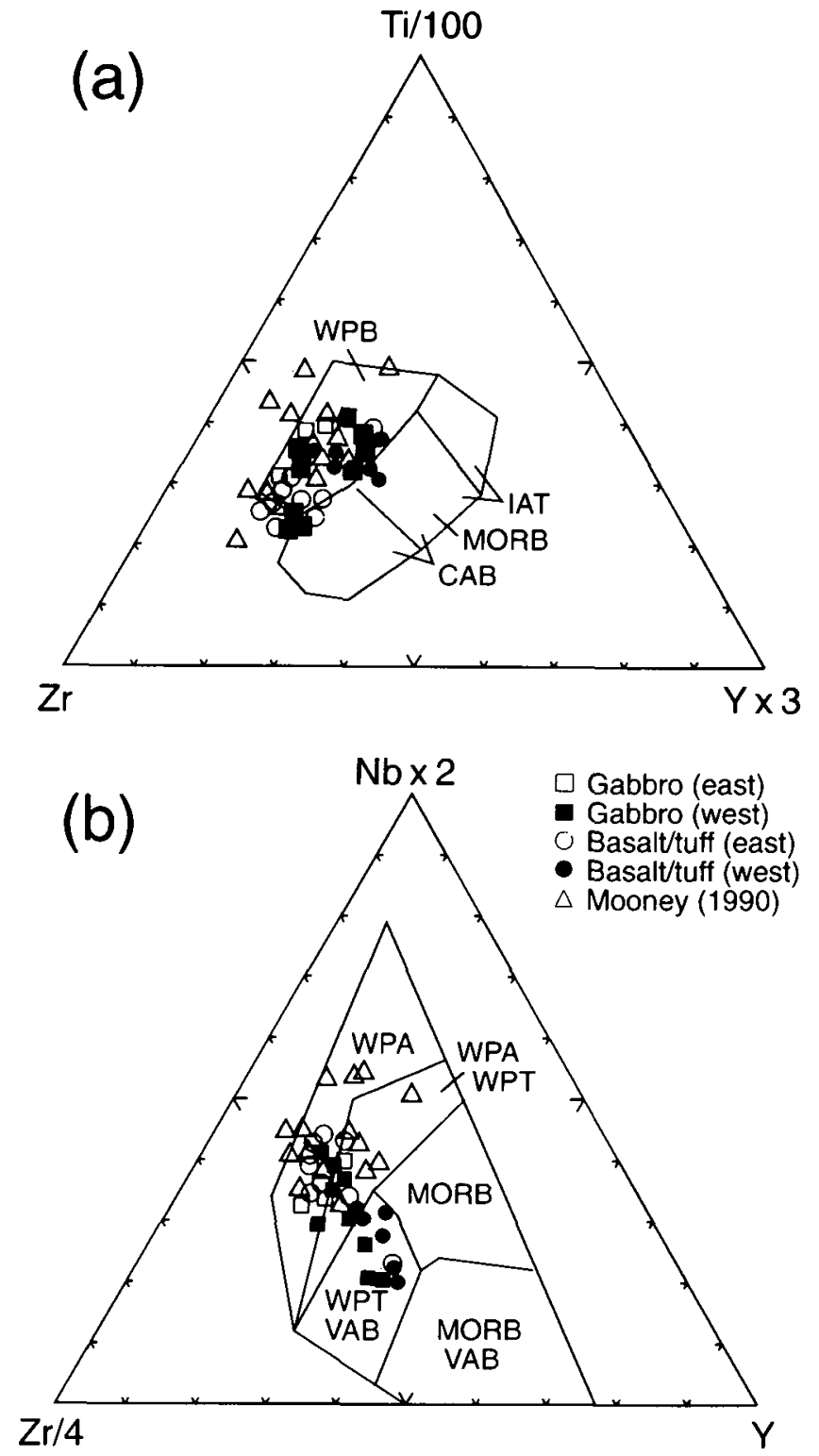

Fig. 7. Tectonic setting discrimination diagrams for mafic samples, with fields from (a) Pearce and Cann (1973) and (b) Meschede (1986).

Brook Formation in Cape Breton Island (Smith in Williams et al., 1985) or with the middle Devonian McAras Brook formation of the Antigonish Highlands (Donohoe and Grantham, 1989). The U-Pb date of $389 \pm 2 \mathrm{Ma}$ indicates that the volcanic rocks of the Sunnyville Formation are older than those of the Fisset Brook Formation, from which rhyolites have yielded ages of ca. $375 \mathrm{Ma}$, both in the type section in Fisset Brook (D. Piper, personal communication, 1995; G. Dunning, unpublished data) and in the Gillanders Mountain area (Barr et al., 1995). The McAras Brook formation is similar to the Sunnyville Formation in that it includes mafic rocks with characteristics of both tholeiitic and alkalic withinplate basalts (Dostal et al., 1983; Murphy, 1987). Fossils in the McAras Brook formation suggest a Middle Devonian age (Boucot et al., 1974), the same as the age of the Sunnyville Formation based on the U-Pb date and the Okulitch (1995) 

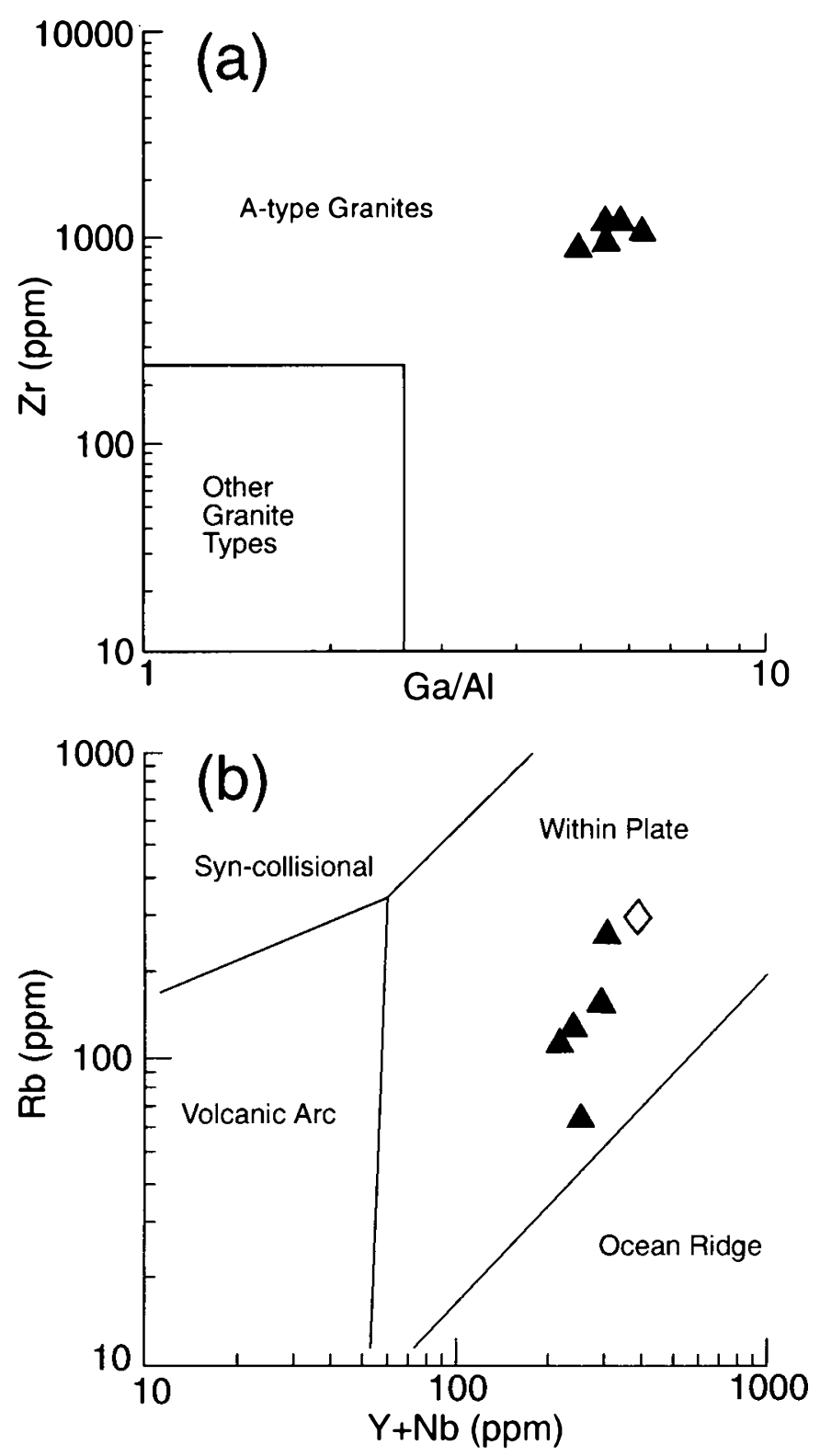

Fig. 8. Plots of (a) $\mathrm{Zr}$ vs. $\mathrm{Ga} / \mathrm{Al}$ and (b) $\mathrm{Rb}-\mathrm{Y}+\mathrm{Nb}$ for felsic samples (black triangles). Fields are from (a) Whalen et al. (1987) and (b) Pearce et al. (1984). A rhyolite sample (diamond symbol) from the Naivasha volcanic field in the Kenya Rift (from Wilson, 1989, p. 348) is shown for comparison.

time scale. However, no gabbroic or felsic rocks appear to be present in the McAras Brook formation.

The early Middle Devonian age of ca. 389 Ma for rhyolite in the Sunnyville Formation suggests that the overlying Glenkeen Formation and quartz wacke/siltstone units are older than the Horton Group, which overlies ca. $373 \mathrm{Ma}$ rhyolite (G.R. Dunning, unpublished data) of the Fisset Brook Formation in Cape Breton Island. The only fossil control on the age of the Guysborough area units is sparse plant debris and poorly preserved pelecypods which indicate a Devonian or younger age (Smith in Williams et al., 1985). However, the presence of gabbroic rocks with an age ca. $385 \mathrm{Ma}$ shows that all of the sedimentary host rocks are of similar early Middle Devonian age. The gabbros are older
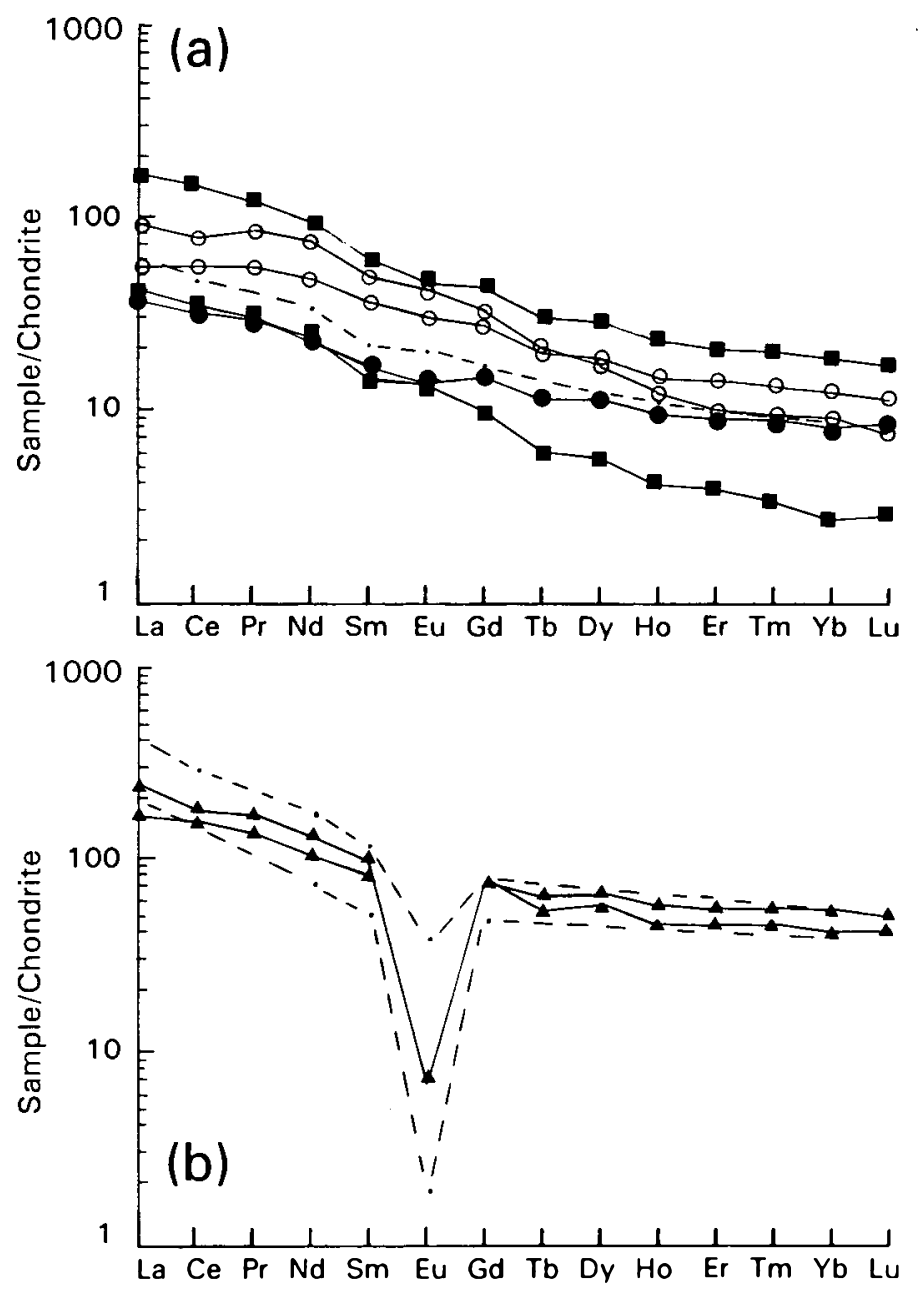

Fig. 9. Plots of chondrite-normalized data for (a) mafic samples and (b) felsic samples (symbols as in Fig. 5). Transitional basalt and rhyolite samples from the Boina centre, Afar Rift (Wilson, 1989, p. 347) and Naivasha volcanic field, Kenya Rift (Wilson, 1989 , p. 348) are shown for comparison (dashed lines). Chondrite-normalizing values are from Haskin et al. (1968).

than gabbros in the St. Peters area of southern Cape Breton Island (Fig. 1), which have yielded an age of $340 \mathrm{Ma}$ (Barr et al., 1994).

An attribute shared by many Devonian to Carboniferous volcanic and plutonic rocks in northern mainland Nova Scotia and Cape Breton Island is the behaviour of the $\mathrm{Rb}-\mathrm{Sr}$ isotopic system. Basaltic and rhyolitic samples from this study, analysed by R. Cormier at St. Francis Xavier University, have yielded an isochron which gives an apparent age of $334 \pm 4 \mathrm{Ma}$ (R. Cormier, personal communication, 1994), similar to the apparent Rb-Sr age obtained for the Fisset Brook Formation (Cormier and Kelley, 1964; Keppie and Smith, 1978; Huard, 1984). The significance of these Early Carboniferous ages is uncertain. All samples (rhyolite, basalt and gabbro) plot on a single isochron, suggesting that they may have been reset by a post-igneous overprinting event, as it is unlikely that the felsic and mafic rocks had the same initial isotopic ratio. The initial ratio is appropriate only for crustal melts and may not be a primary signature. The difference between $\mathrm{U}-\mathrm{Pb}$ and $\mathrm{Rb}-\mathrm{Sr}$ ages derived 
from the same rocks suggests that caution should be exercised in interpretation of $\mathrm{Rb}-\mathrm{Sr}$ data, and the concordant $\mathrm{U}$ $\mathrm{Pb}$ ages are considered more reliable.

Volcanic and gabbroic rocks ranging in age from late Silurian through early Carboniferous are widespread in the northern Appalachian region (e.g., Fig. 1). All appear to have formed in a continental, within-plate setting (this study and Blanchard et al., 1984; Bradley, 1982, 1983; Pe-Piper et al., 1989; Baldwin, 1991; Van Wagoner et al., 1989; Dostal et al., 1989, 1994; Doig et al., 1991; Hon et al., 1992). Thus the Sunnyville Formation is part of a continuum of extensional magmatism which extended from the Silurian in northwestern New Brunswick into the Carboniferous in the Magdalen Basin, Cape Breton Island and locally elsewhere (e.g., Barr et al., 1994; Fyffe and Barr, 1986). As better constraints on age and petrochemistry, such as those of the present study, become available, an assessment of timespace variation in and tectonic implications of igneous activity associated with the Maritimes Basin will be possible.

\section{ACKNowledgements}

Financial support for this project came mainly from a Natural Sciences and Engineering Research Council of Canada Research Grant to SMB, and a contract to SMB through the Canada - Nova Scotia Cooperation Agreement on Mineral Development through the Geological Survey of Canada. We thank Robert Ryan of the Nova Scotia Department of Natural Resources and Energy for contributing to the cost of $U$ $\mathrm{Pb}$ dating. CFMC was supported in part by an Acadia University Graduate Fellowship during her M.Sc. programme. We thank Paul K. Smith, an anonymous reviewer, and editor Graham Williams for their helpful comments which led to improvements in the manuscript.

BALDWIN, D. 1991. Physical volcanology, geochemistry, and depositional setting of Siluro - Devonian volcanic rocks near St. Andrews, New Brunswick. M.Sc. thesis, Acadia University, Wolfville, Nova Scotia.

Barr, S.M. and White, C.E. 1995. Devonian to Carboniferous stratigraphy in the Guysborough - Mulgrave - L'Ardoise area, Nova Scotia. Nova Scotia Department of Natural Resources, Mines and Energy Branch, Report 95-2, p. 57.

Barr, S.M., White, C.E., and Graves, M. 1992. Meguma terrane in southern Cape Breton Island? Atlantic Geology, 28, p. 194.

Barr, S.M., Grammatikopoulos, A.L., and Dunning, G.R. 1994. Early Carboniferous gabbro and basalt in the St. Peters area, southern Cape Breton Island, Nova Scotia. Atlantic Geology, 30, pp. 247-258.

Barr, S.M., Macdonald, A.S., Arnott, A.M., and Dunning, G.R. 1995. The Fisset Brook Formation in the Lake Ainslie - Gillanders Mountain area, central Cape Breton Island, Nova Scotia. Atlantic Geology, 31, pp. 127-139.

Blanchard, M., Jamieson, R.A., and More, E.B. 1984. Late Devonian - Early Carboniferous volcanism in western Cape Breton Island, Nova Scotia. Canadian Journal of Earth Sciences, 21 , pp. 762-774.

Boucot, A.J., Dewey, J.F., Dineley, D.L., Fletcher, R., Fyson, W.K., GriffiN, J.G., Hickox, C.F., McKerrow, W.S., and ZiEGLER, A.M. 1974. Geology of the Arisaig area Antigonish County,
Nova Scotia. Geological Society of America, Special Paper, $139,191 \mathrm{p}$.

Bradley, D.C. 1982. Subsidence in Late Paleozoic basins in the northern Appalachians. Tectonics, 1, pp. 107-123.

---- 1983. Tectonics of the Acadian Orogeny in New England and adjacent Canada. Journal of Geology, 91, pp. 381-400.

CORMIER, C.F.M. 1994. Field relations, petrology, and age of volcanic and associated sedimentary and gabbroic rocks in the Guysborough area, Nova Scotia. M.Sc. thesis, Acadia University.

Cormier, R.F. and Kelly, A.M. 1964. Absolute age of the Fisset Brook Formation and the Devonian-Mississippian Boundary, Cape Breton Island, Nova Scotia. Canadian Journal of Earth Sciences, 1, pp. 159-166.

Cullers, R.L. and Graf, J.L. 1984. Rare earth elements in igneous rocks of the continental crust: predominantly basic and ultrabasic rocks. In Rare earth element geochemistry. Edited by P. Henderson. Elsevier Science Publishers, Amsterdam, pp. 237-274.

DıckIE, G.B. 1989. Building stone project, Erinville, Guysborough County and South River Lake, Antigonish County. Nova Scotia Department of Mines and Energy, Report 89-3, p. 31.

Doig, R., Murphy, J.B., Nance, R.D., and Stokes, T. 1991. Review of the geochronology of the Cobequid Highlands, Avalon Composite Terrane, Nova Scotia. In Current Research, Part D, Geological Survey of Canada, Paper 91-1D, pp. 71-78.

Donohoe, H.V., JR. and Grantham, R.G. 1989. Geological highway map of Nova Scotia, second edition. Atlantic Geoscience Society, Special Publication No. 1, Halifax, Nova Scotia.

Dostal, J., KeppIE, J.D., DupuY, C. 1983. Petrology and geochemistry of Devono-Carboniferous volcanic rocks in Nova Scotia. Maritime Sediments and Atlantic Geology, 19, pp. 59-71.

Dostal, J., Wilson, R.A., and KePPIE, J.D. 1989. Geochemistry of Siluro-Devonian Tobique Volcanic belt in northern and central New Brunswick (Canada): tectonic implications. Canadian Journal of Earth Sciences, 26, pp. 1282-1296.

Dostal, J., Laurent, R., and Keppie, J.D. 1994. Late SilurianEarly Devonian rifting during transpression in the southern Gaspe Peninsula (Quebec): petrogenesis of volcanic rocks. Canadian Journal of Earth Sciences, 30, pp. 2283-2294.

Dunning, G.R., O'Brien, S.J., Colman-Sadd, S.P., Blackwood, R.F., Dickson, W.L., O'Neill, P.P., and KroGh, T.E. 1990. Silurian orogeny in the Newfoundland Appalachians. Journal of Geology, 98, pp. 895-913.

Durocher, A.C. 1974. Basic magmatism in Nova Scotia. B.Sc. thesis, Acadia University, Wolfville, Nova Scotia.

EDmonds, S.L. 1990. Petrology of dioritic and gneissic rocks in the Melrose area, eastern Nova Scotia. B.Sc. thesis, Acadia University, Wolfville, Nova Scotia.

Floyd, P.A. and Winchester, J.A. 1978. Identification and discrimination of altered and metamorphosed volcanic rocks using immobile elements. Chemical Geology, 21, pp. 291306.

Fyffe, L.R. and BARR, S.M. 1986. Petrochemistry and tectonic significance of Carboniferous volcanic rocks in New Brunswick. Canadian Journal of Earth Sciences, 23, pp. 1243-1256.

Gibbons, W. and Murphy, J.B. 1993. The crustal root of the Minas Fault System: new evidence from Clarke Head, Nova Scotia. Geological Society of America, Abstracts, 23:2, p. 18.

Hanson, G.N. 1980. Rare earth elements in petrogenetic studies of igneous systems. Annual Review of Earth and Planetary Science, 8, pp. 371-406.

HASkin, L.A., Haskin, M.A., and Frey, F.A. 1968. Relative and terrestrial abundances of the rare earths. In Origin and distribution of the elements. Edited by L.H. Aherns. Pergamon, Oxford, United Kingdom, pp. 889-912. 
HiLL, J.D. 1987. Geology of the Guysborough-Country Harbour area, Nova Scotia. In Current Research, Part A, Geological Survey of Canada, Paper 87-1A, pp. 415- 422.

---- 1991. Petrology, tectonic significance and economic potential of Devonian peraluminous granitoid plutons in the Canso and Forest Hill areas, Eastern Meguma Terrane, Nova Scotia. Geological Survey of Canada, Bulletin 383, 96 p.

Hon, R., Fitzgerald, J.P., Sargent, S.L., and Schwartz, W.D. 1992. Silurian-Early Devonian mafic rocks of the Piscataquis volcanic belt in northern Maine. Atlantic Geology, 28, pp. 163-170.

Huard, A.A. 1984. The Carboniferous volcanic rocks at Lake Ainslie, Nova Scotia: implications for tectonic regime and barite mineralization. B.Sc. thesis, St. Francis Xavier University, Antigonish, Nova Scotia.

KePpIE, J.D. 1979. Geological map of Nova Scotia. Nova Scotia Department of Mines and Energy, scale 1:500,000.

KeppiE, J.D. and SMith, P.K. 1978. Compilation of isotopic age data of Nova Scotia. Nova Scotia Department of Mines Report 78-4.

KROGH, T.E. 1982. Improved accuracy of U-Pb zircon ages by the creation of more concordant systems using an air abrasion technique. Geochimica et Cosmochimica Acta, 46, pp. 637-649.

Meschede, M. 1986. A method of discriminating between different types of mid-ocean ridge basalts and continental tholeiites with the Nb-Zr-Y diagram. Chemical Geology, 56, pp. $207-$ 218.

Mooney, S. 1990. Stratigraphy of two late Paleozoic basins: implications for the timing of final emplacement of the Meguma Terrane. M.Sc. thesis, Lakehead University, Thunder Bay, Ontario.

Murphy, J.B. 1987. Late Precambrian to Late Devonian mafic magmatism in the Antigonish Highlands of Nova Scotia: multistage melting of a hydrated mantle. Canadian Journal of Earth Sciences, 25, pp. 473-485.

Murphy, J.B., Meagher, C., and Mosher, S.J. 1993. Geological evolution of the eastern St. Mary's basin: preliminary results. Nova Scotia Department of Natural Resources, Mines and Energy branches, Report 93-2, p. 53.

Okulitch, A.V. 1995. Geological time chart, 1995. Geological Survey of Canada, Open File 3040.

Pearce, J.A. 1982. Trace element characteristics of lavas from destructive plate boundaries. In Andesites: Orogenic Andesites and Related Rocks. Edited by R.S. Thorpe. John Wiley and Sons, New York, pp. 525-548.

Pearce, J.A. and Cann, J.R. 1973. Tectonic setting of basic volcanic rocks using trace element analyses. Earth and Planetary Science Letters, 19, pp. 290-300.

Pearce, J.A., Harris, N.B.W., and Tindle, A.G. 1984. Trace element discrimination diagrams for the tectonic interpretation of granitic rocks. Journal of Petrology, 25, pp. 956-983.
Pe-Piper, G., Cormier, R.F., and Piper, D.J.W. 1989. The age and significance of Carboniferous plutons of the western Cobequid Highlands, Nova Scotia. Canadian Journal of Earth Science, 26, pp. 1297-1307.

Shervals, J.W. 1982. Ti-V plots and the petrogenesis of modern and ophiolitic lavas. Earth and Planetary Science Letters, 59, pp. 101-118.

SChiller, E.A. 1961. Guysborough. Geological Survey of Canada, Map 27-1961, Scale 1:63,360.

-.--- 1963. Mineralogy and Geology of the Guysborough area, Nova Scotia. Ph.D. thesis, University of Utah.

Shand, S.J. 1947. Eruptive rocks, their genesis, composition classification and their relation to ore deposits, with a chapter on meteorites, 3rd Edition. Thomas Murby, London, $488 \mathrm{p}$.

$\mathrm{S}_{\mathrm{MIT}}$, P.K. 1980. Horton Group stratigraphy in the Guysborough area, Nova Scotia. Nova Scotia Department of Mines and Energy, Report 80-1, p. 109.

---- 1981. Horton Group stratigraphy in the Guysborough area, Nova Scotia. Nova Scotia Department of Mines and Energy, Report 81-1, p. 37.

StaceY, J.S. and Kramers, J.D. 1975. Approximation of terrestrial lead isotope evolution by a two-stage model. Earth and Planetary Science Letters, 26, pp. 207-221.

Van Wagoner, N.A., McNeil, W., and Fay, V. 1989. Early Devonian bimodal volcanic rocks of southwestern New Brunswick: petrography, stratigraphy and depositional setting. Maritime Sediments and Atlantic Geology, 24, pp. 301-319.

Weaver, B.L. and TARNeY, J. 1981. Chemistry of the sub-continental mantle: inferences from Archaean and Proterozoic dykes and continental flood basalts. In Continental basalts and mantle xenoliths. Edited by C.J. Hawkesworth and M.J. Norry, pp. 209-249.

Whalen, J.B., Currie, K.L., and Chappell, B.W. 1987. A-type granites: geochemical characteristics, discrimination, and petrogenesis. Contributions to Mineralogy and Petrology, 95, pp. 407-419.

Williams, G.L., Fyffe, L.R., Wardle, R.J., Colman-Sadd, S.P., and Boenner, R.C. 1985. Lexicon of Canadian Stratigraphy, VI, Atlantic Region.

WILSON, M. 1989. Igneous Petrogenesis: a global tectonic approach. Unwin Hyman Limited, United Kingdom, pp. 1-466.

Winchester, J.A. and FloYd, P.A. 1977. Geochemical discrimination of different magma series and their differentiation products using immobile elements. Chemical Geology, 20, pp. 325-343.

Editorial Responsibility: P. Giles and G.L. Williams 